Article

\title{
Cation, Anion and Ion-Pair Complexes with a G-3 Poly(ethylene imine) Dendrimer in Aqueous Solution
}

\author{
Matteo Savastano ${ }^{1}$, Carla Bazzicalupi ${ }^{1}$, Claudia Giorgi ${ }^{1}$, Paola Gratteri ${ }^{2}$ and Antonio Bianchi ${ }^{1 \text {,* }}$ \\ 1 Department of Chemistry "Ugo Schiff”, via della Lastruccia 3, 50019 Sesto Fiorentino, Italy; \\ matteo.savastano@unifi.it (M.S.); carla.bazzicalupi@unifi.it (C.B.); Claudia.giorgi@unifi.it (C.G.) \\ 2 NEUROFARBA Department, Pharmaceutical and Nutraceutical Section, and Laboratory of Molecular \\ Modeling Cheminformatics \& QSAR, University of Florence, Via Ugo Schiff 6, 50019 Sesto Fiorentino, Italy; \\ paola.gratteri@unifi.it \\ * Correspondence: antonio.bianchi@unifi.it; Tel.: +39-055-457-3254
}

Academic Editor: Ashok Kakkar

Received: 12 April 2017; Accepted: 12 May 2017; Published: 16 May 2017

\begin{abstract}
The G-3 poly(ethylene imine) ligand L2 shows a multifaceted coordination ability, being able to bind metal cations, anions and ion-pairs. The equilibrium constants for the formation of metal $\left(\mathrm{Cu}^{2+}, \mathrm{Zn}^{2+}\right)$, anion $\left(\mathrm{SO}_{4}{ }^{2-}\right)$ and ion-pair $\left(\mathrm{Cu}^{2+} / \mathrm{SO}_{4}{ }^{2-}\right)$ complexes were determined in $0.1 \mathrm{M} \mathrm{Me}_{4} \mathrm{NCl}$ aqueous solution at $298.1 \pm 0.1 \mathrm{~K}$ by means of potentiometric titrations. Thanks to its dendrimeric nature, $\mathrm{L} 2$ can form highly nucleated metal complexes, such as $\mathrm{Cu}_{5} \mathrm{~L}^{10+}$ and $\mathrm{Zn}_{4} \mathrm{~L}^{8+}$, in successive and well-defined complexation steps. Protonated forms of L2 give rise to relatively weak anion complexes with $\mathrm{SO}_{4}{ }^{2-}$, but the addition of $\mathrm{Cu}^{2+}$ significantly enhances the binding ability of the ligand toward this anion below $\mathrm{pH}$ 9. In more alkaline solutions, an opposite trend is observed. The coordination properties of L2 are discussed with the support of modelling calculations. According to results, L2 is a promising molecule for the preparation of solid supported materials for the recovery of cations and anions from aqueous media and/or for applications in heterogeneous catalysis.
\end{abstract}

Keywords: copper; zinc; dendrimers; poly(ethylene imine); polynuclear complexes; anion complexes; ion-pair complexes

\section{Introduction}

In recent papers, we showed that the G-2 poly(ethylene imine) dendrimer L1 (Figure 1) and its variously protonated forms are able to assemble stable cation, anion and ion-pair complexes in aqueous solution [1-4]. Such ability appears to be a propagation and an enhancement of the properties of the parent ligand tris(2-aminoethyl)amine (tren), which is historically known to bind metal complexes and, more recently, has also been accredited as a rather efficient anion receptor [5]. Indeed, regarding the coordination of metal ions, while tren forms stable mononuclear complexes, L1 can bind two metal ions such as $\mathrm{Ni}^{2+}, \mathrm{Zn}^{2+}$ and $\mathrm{Cd}^{2+}$ and up to three $\mathrm{Cu}^{2+}$ and $\mathrm{Hg}^{2+}$ ions [1,4]. $\mathrm{L} 1$ and its metal complexes are also able to bind inorganic anions [2] as well as the anionic forms of AMP, ADP and ATP nucleotides acting as catalysts that enhance significantly ATP dephosphorylation in aqueous solution [3]. Construction of a third generation of ethylamino branches around L1 gave rise to the G-3 poly(ethylene imine) dendrimer L2 (Figure 1) that is also able to bind anions, such as $\mathrm{PO}_{4}{ }^{3-}$, $\mathrm{P}_{2} \mathrm{O}_{7}{ }^{4-}$ and $\mathrm{P}_{3} \mathrm{O}_{10}{ }^{5-}$, and AMP, ADP and ATP nucleotides. In particular, $\mathrm{L} 2$ showed an unprecedented behaviour toward ATP, the dendrimer being able to enhance or inhibit dephosphorylation of the nucleotide depending on the solution $\mathrm{pH}[6]$. 
<smiles>NCCN(CCN)CCN(CCN(CCN)CCN)CCN(CCN)CCN</smiles>

L1<smiles>NCCN(CCN)CCN(CCN(CCN)CCN)CCN(CCN(CCN(CCN)CCN)CCN(CCN)CCN)CCN(CCN(CCN)CCN)CCN(CCN)CCN</smiles>

L2

Figure 1. G-2 (L1) and G-3 (L2) poly(ethylene imine) dendrimers.

Despite the discovery of such properties towards nucleotide and phosphate type anions, the ability of L2 to bind metal cations, inorganic anions and ion-pairs remains unexplored. Actually, L2 is a very interesting ligand for the formation of metal complexes, in particular of polynuclear assemblies, since it contains a large number (22) of nitrogen donor atoms in its molecular structure, and accordingly, it should be able to form complexes of greater nuclearity than the smaller homologous L1. It is worth of note that there is a great deal of interest toward polynuclear metal complexes, especially for their catalytic properties and/or for their use in the generation of metal nanoparticle-based catalysts [7-10].

This has aroused our interest in performing a detailed analysis of the complexation equilibria involving L2, metal cations and anions in aqueous solution. As previously noted [1], to study similar complexation systems is an arduous task, due to the many equilibria involving the stepwise coordination of several metal ions involving several protonation states for each complexation step. Attempts to perform the speciation of complex systems and determining the equilibrium constants for complexation equilibria with other poly(ethylene imine) dendrimers were made by considering the repeating triamine units of the dendrimer as identical independent ligand molecules, under the implicit assumption that these repeating units were uniformly distributed in solution, in contrast to their actual localization within the same dendrimer molecule [11]. These studies were performed under conditions approaching the ligand coordinative saturation, the metal-to-triamine unit ratios being closed to 1:1 and extending it, at most, up to 1:4.

Despite such an approximation, the results of these studies can be functional for the purposes for which they are developed, although they furnish an incomplete picture of the complexation systems. In particular, this approach leads to the identification of a limited number of complex species relative to the many that these dendrimers can form. For instance, dendrimers containing large numbers of amino groups are expected to bind metal ions even when they are extensively protonated. Some of the missing species could have interesting properties, like the ability of highly protonated $\mathrm{Zn}(\mathrm{II})$ complexes with L1 to promote the binding and the dephosphorylation of ATP [3].

In this paper, we report the results of a detailed analysis of the complexation systems formed by $\mathrm{L} 2$ with $\mathrm{Zn}^{2+}$ and $\mathrm{Cu}^{2+}$ that led to the identification of 35 and 42 complex species for $\mathrm{Zn}^{2+}$ and $\mathrm{Cu}^{2+}$, respectively, the ligand achieving the stepwise coordination of $4 \mathrm{Zn}^{2+}$ or $5 \mathrm{Cu}^{2+}$ ions. Once these complexation systems were clearly defined, we analysed the ability of $\mathrm{L} 2$ to interact with $\mathrm{SO}_{4}{ }^{2-}$ both in the absence and in the presence of $\mathrm{Cu}^{2+}$.

\section{Results and Discussion}

\subsection{Formation of Metal Complexes}

Speciation of $\mathrm{L} 2 / \mathrm{Cu}^{2+}$ and $\mathrm{L} 2 / \mathrm{Zn}^{2+}$ complex systems and determination of the relevant stability constants were performed by means of $\mathrm{pH}$-metric (potentiometric) titrations $\left(0.1 \mathrm{M} \mathrm{Me}_{4} \mathrm{NCl}\right.$, 
$298.1 \pm 0.1 \mathrm{~K})$ and analysis of the associated data by means of the computer program HYPERQUAD [12] which furnished the stability constants collected in Tables 1 and 2 for $\mathrm{Cu}^{2+}$ and $\mathrm{Zn}^{2+}$, respectively. Distribution diagrams of the complexes formed are reported in Figures S1 and S2.

As shown by these tables, the G-3 dendrimer L2 is able to bind in successive steps from one to five $\mathrm{Cu}^{2+}$ cations and from one to four $\mathrm{Zn}^{2+}$ ions. According to the presence of many (22) nitrogen donor atoms in the ligand, all complexes but $\mathrm{Cu}_{5} \mathrm{~L}_{2}{ }^{10+}$ are able to bind protons, and the number of protonated species they form decreases with increasing complex nuclearity. It was previously reported that protonation of the primary amine groups of L2 is associated with protonation constants $\log K \geq 8.3$ [6]. Considering this value as the limiting value for protonation of primary amine groups also in L2 complexes, we can deduce from the equilibrium data in Table 1 that, in $\mathrm{CuL}_{2}{ }^{2+}$, there are nine primary amine groups, out of 12 , that are not involved in metal coordination. By similar reasoning, and taking into account the experimental errors on the determined equilibrium constants, the number of uncoordinated primary nitrogens can be reasonably estimated as six in $\mathrm{Cu}_{2} \mathrm{~L}_{2}{ }^{4+}$, five in $\mathrm{Cu}_{3} \mathrm{~L}^{6+}$, three in $\mathrm{Cu}_{4} \mathrm{~L}^{8+}$, and none in $\mathrm{Cu}_{5} \mathrm{~L}^{10+}$. The equilibrium constants for the successive binding of the first and the second $\mathrm{Cu}^{2+}$ ions are very high $(\log K=23.66$ and 22.9, Table 1$)$ and consistent with the stability of hexacoordinated $\mathrm{Cu}^{2+}$ complexes of polyamines $[13,14]$. Accordingly, the first two $\mathrm{Cu}^{2+}$ ions binding L2 should be coordinated by three primary and three secondary amine groups near the surface of the G-3 dendrimer. The third coordination stage causes a greater involvement of the inner dendrimer region, since only one primary amine group is involved in the equilibrium $\mathrm{Cu}_{2} \mathrm{~L}^{4+}+\mathrm{Cu}^{2+}$ $=\mathrm{Cu}_{3} \mathrm{~L} 2^{6+}$. This appears to be a poorly favourable coordination step as shown by the surprisingly low value of the corresponding equilibrium constant $(\log K=10.0$, Table 1$)$.

Table 1. Stability constants of $\mathrm{Cu}^{2+}$ complexes with L2. $0.1 \mathrm{M} \mathrm{Me}_{4} \mathrm{NCl}, 298.1 \pm 0.1 \mathrm{~K}$. Values in parentheses are standard deviation on the last significant figure.

\begin{tabular}{|c|c|c|c|}
\hline Equilibria & $\log K$ & Equilibria & $\log K$ \\
\hline $\mathrm{Cu}^{2+}+\mathrm{L} 2=\mathrm{CuL} 2^{2+}$ & $23.66(5)$ & $\mathrm{Cu}_{2} \mathrm{H}_{7} \mathrm{~L}_{2}{ }^{11+}+\mathrm{H}^{+}=\mathrm{Cu}_{2} \mathrm{H}_{8} \mathrm{~L}_{2}^{12+}$ & $7.46(8)$ \\
\hline $\mathrm{CuL}_{2}^{2+}+2 \mathrm{H}^{+}=\mathrm{CuH}_{2} \mathrm{~L}^{4+}$ & $22.88(7)$ & $\mathrm{Cu}_{2} \mathrm{H}_{8} \mathrm{~L}^{12+}+\mathrm{H}^{+}=\mathrm{Cu}_{2} \mathrm{H}_{9} \mathrm{~L}^{13+}$ & $6.25(8)$ \\
\hline $\mathrm{CuH}_{2} \mathrm{~L}^{4+}+\mathrm{H}^{+}=\mathrm{CuH}_{3} \mathrm{~L}^{5+}$ & $9.93(5)$ & $\mathrm{Cu}_{2} \mathrm{H}_{9} \mathrm{~L}^{13+}+\mathrm{H}^{+}=\mathrm{Cu}_{2} \mathrm{H}_{10} \mathrm{~L}^{14+}$ & $4.98(7)$ \\
\hline $\mathrm{CuH}_{3} \mathrm{~L}^{5+}+\mathrm{H}^{+}=\mathrm{CuH}_{4} \mathrm{~L}^{6+}$ & $10.07(5)$ & $\mathrm{Cu}_{2} \mathrm{H}_{10} \mathrm{~L}^{14+}+\mathrm{H}^{+}=\mathrm{Cu}_{2} \mathrm{H}_{11} \mathrm{~L}^{15+}$ & $4.07(7)$ \\
\hline $\mathrm{CuH}_{4} \mathrm{~L}^{2+}+\mathrm{H}^{+}=\mathrm{CuH}_{5} \mathrm{~L}^{7+}$ & $9.42(3)$ & & \\
\hline $\mathrm{CuH}_{5} \mathrm{~L}_{2}^{7+}+\mathrm{H}^{+}=\mathrm{CuH}_{6} \mathrm{~L}^{8+}$ & $9.21(7)$ & $3 \mathrm{Cu}^{2+}+\mathrm{L} 2=\mathrm{Cu}_{3} \mathrm{~L}^{6+}$ & $56.55(7)$ \\
\hline $\mathrm{CuH}_{6} \mathrm{~L}_{2}^{8+}+\mathrm{H}^{+}=\mathrm{CuH}_{7} \mathrm{~L}^{9+}$ & $9.09(7)$ & $\mathrm{Cu}_{2} \mathrm{~L}^{4+}+\mathrm{Cu}^{2+}=\mathrm{Cu}_{3} \mathrm{~L}^{6+}$ & $10.0(1)$ \\
\hline $\mathrm{CuH}_{7} \mathrm{~L}_{2}{ }^{9+}+\mathrm{H}^{+}=\mathrm{CuH}_{8} \mathrm{~L}^{10+}$ & $8.63(5)$ & $\mathrm{Cu}_{3} \mathrm{~L}^{6+}+2 \mathrm{H}^{+}=\mathrm{Cu}_{3} \mathrm{H}_{2} \mathrm{~L}^{8+}$ & $22.72(6)$ \\
\hline $\mathrm{CuH}_{8} \mathrm{~L}_{2}{ }^{10+}+\mathrm{H}^{+}=\mathrm{CuH}_{9} \mathrm{~L}^{11+}$ & $8.50(4)$ & $\mathrm{Cu}_{3} \mathrm{H}_{2} \mathrm{~L}^{8+}+\mathrm{H}^{+}=\mathrm{Cu}_{3} \mathrm{H}_{3} \mathrm{~L}^{9+}$ & $10.31(7)$ \\
\hline $\mathrm{CuH}_{9} \mathrm{~L}^{11+}+\mathrm{H}^{+}=\mathrm{CuH}_{10} \mathrm{~L}^{12+}$ & $8.13(4)$ & $\mathrm{Cu}_{3} \mathrm{H}_{3} \mathrm{~L}^{9+}+\mathrm{H}^{+}=\mathrm{Cu}_{3} \mathrm{H}_{4} \mathrm{~L}^{10+}$ & $8.87(8)$ \\
\hline $\mathrm{CuH}_{10} \mathrm{~L}_{2}^{12+}+\mathrm{H}^{+}=\mathrm{CuH}_{11} \mathrm{~L}^{13+}$ & $7.49(4)$ & $\mathrm{Cu}_{3} \mathrm{H}_{4} \mathrm{~L}^{10+}+\mathrm{H}^{+}=\mathrm{Cu}_{3} \mathrm{H}_{5} \mathrm{~L}^{11+}$ & $8.50(8)$ \\
\hline $\mathrm{CuH}_{11} \mathrm{~L}_{2}^{13+}+\mathrm{H}^{+}=\mathrm{CuH}_{12} \mathrm{~L}_{2}^{14+}$ & $5.87(4)$ & $\mathrm{Cu}_{3} \mathrm{H}_{5} \mathrm{~L}^{11+}+\mathrm{H}^{+}=\mathrm{Cu}_{3} \mathrm{H}_{6} \mathrm{~L}^{12+}$ & $7.39(7)$ \\
\hline $\mathrm{CuH}_{12} \mathrm{~L}_{2}^{14+}+\mathrm{H}^{+}=\mathrm{CuH}_{13} \mathrm{~L}_{2}^{15+}$ & $5.18(4)$ & $\mathrm{Cu}_{3} \mathrm{H}_{6} \mathrm{~L}^{12+}+\mathrm{H}^{+}=\mathrm{Cu}_{3} \mathrm{H}_{7} \mathrm{~L}_{2}^{13+}$ & $6.82(8)$ \\
\hline $\mathrm{CuH}_{13} \mathrm{~L}_{2}^{15+}+\mathrm{H}^{+}=\mathrm{CuH}_{14} \mathrm{~L}_{2}^{16+}$ & $3.94(5)$ & $\mathrm{Cu}_{3} \mathrm{H}_{7} \mathrm{~L}^{13+}+\mathrm{H}^{+}=\mathrm{Cu}_{3} \mathrm{H}_{8} \mathrm{~L}_{2}^{14+}$ & $5.81(8)$ \\
\hline $\mathrm{CuH}_{14} \mathrm{~L}_{2}^{16+}+\mathrm{H}^{+}=\mathrm{CuH}_{15} \mathrm{~L}_{2}^{17+}$ & $2.59(5)$ & & \\
\hline \multirow[t]{2}{*}{$\mathrm{CuH}_{15} \mathrm{~L}^{17+}+\mathrm{H}^{+}=\mathrm{CuH}_{16} \mathrm{~L}^{18+}$} & $2.89(6)$ & $4 \mathrm{Cu}^{2+}+\mathrm{L} 2=\mathrm{Cu}_{4} \mathrm{~L}^{8+}$ & $72.6(1)$ \\
\hline & & $\mathrm{Cu}_{3} \mathrm{~L}_{2}^{6+}+\mathrm{Cu}^{2+}=\mathrm{Cu}_{4} \mathrm{~L}^{8+}$ & $16.0(1)$ \\
\hline $2 \mathrm{Cu}^{2+}+\mathrm{L} 2=\mathrm{Cu}_{2} \mathrm{~L}^{4+}$ & $46.53(7)$ & $\mathrm{Cu}_{4} \mathrm{~L}^{8+}+2 \mathrm{H}^{+}=\mathrm{Cu}_{4} \mathrm{H}_{2} \mathrm{~L}^{8+}$ & $22.5(1)$ \\
\hline $\mathrm{CuL} 2^{2+}+\mathrm{Cu}^{2+}=\mathrm{Cu}_{2} \mathrm{~L}^{4+}$ & $22.9(1)$ & $\mathrm{Cu}_{4} \mathrm{H}_{2} \mathrm{~L}^{10+}+\mathrm{H}^{+}=\mathrm{Cu}_{4} \mathrm{H}_{3} \mathrm{~L}^{11+}$ & $8.54(1)$ \\
\hline $\mathrm{Cu}_{2} \mathrm{~L}^{4+}+\mathrm{H}^{+}=\mathrm{Cu}_{2} \mathrm{HL}_{2}{ }^{5+}$ & $11.51(6)$ & $\mathrm{Cu}_{4} \mathrm{H}_{3} \mathrm{~L}^{11+}+\mathrm{H}^{+}=\mathrm{Cu}_{4} \mathrm{H}_{4} \mathrm{~L}^{12+}$ & $7.3(1)$ \\
\hline $\mathrm{Cu}_{2} \mathrm{HL}_{2}^{5+}+\mathrm{H}^{+}=\mathrm{Cu}_{2} \mathrm{H}_{2} \mathrm{~L}^{6+}$ & $10.20(7)$ & $\mathrm{Cu}_{4} \mathrm{H}_{4} \mathrm{~L}^{12+}+\mathrm{H}^{+}=\mathrm{Cu}_{4} \mathrm{H}_{5} \mathrm{~L}^{13+}$ & $6.9(1)$ \\
\hline $\mathrm{Cu}_{2} \mathrm{H}_{2} \mathrm{~L}^{6+}+\mathrm{H}^{+}=\mathrm{Cu}_{2} \mathrm{H}_{3} \mathrm{~L}^{7+}$ & $9.24(7)$ & $\mathrm{Cu}_{4} \mathrm{H}_{5} \mathrm{~L}^{13+}+\mathrm{H}^{+}=\mathrm{Cu}_{4} \mathrm{H}_{6} \mathrm{~L}^{14+}$ & $3.9(1)$ \\
\hline $\mathrm{Cu}_{2} \mathrm{H}_{3} \mathrm{~L}^{7+}+\mathrm{H}^{+}=\mathrm{Cu}_{2} \mathrm{H}_{4} \mathrm{~L}^{8+}$ & $9.61(6)$ & & \\
\hline $\mathrm{Cu}_{2} \mathrm{H}_{4} \mathrm{~L}_{2}^{8+}+\mathrm{H}^{+}=\mathrm{Cu}_{2} \mathrm{H}_{5} \mathrm{~L}^{9+}$ & $8.31(7)$ & $5 \mathrm{Cu}^{2+}+\mathrm{L} 2=\mathrm{Cu}_{5} \mathrm{~L}^{10+}$ & $82.0(2)$ \\
\hline $\mathrm{Cu}_{2} \mathrm{H}_{5} \mathrm{~L}^{9+}+\mathrm{H}^{+}=\mathrm{Cu}_{2} \mathrm{H}_{6} \mathrm{~L}^{10+}$ & $8.22(7)$ & $\mathrm{Cu}_{4} \mathrm{~L}^{8+}+\mathrm{Cu}^{2+}=\mathrm{Cu}_{5} \mathrm{~L}^{10+}$ & $9.4(3)$ \\
\hline $\mathrm{Cu}_{2} \mathrm{H}_{6} \mathrm{~L}_{2}{ }^{10+}+\mathrm{H}^{+}=\mathrm{Cu}_{2} \mathrm{H}_{7} \mathrm{~L}^{11+}$ & $8.18(7)$ & $\mathrm{Cu}_{5} \mathrm{~L}^{10+}+2 \mathrm{OH}^{-}=\left[\mathrm{Cu}_{5} \mathrm{~L} 2(\mathrm{OH})_{2}\right]^{8+}$ & $8.5(2)$ \\
\hline
\end{tabular}

Such a drop of the metal ion binding constant is, most likely, determined by an important structural rearrangement that the very stable $\mathrm{Cu}_{2} \mathrm{~L}_{2}{ }^{4+}$ complex must bear to accommodate the third $\mathrm{Cu}^{2+}$ ion. Conversely, $\mathrm{Cu}_{3} \mathrm{~L}^{6+}$ displays a greater binding ability toward $\mathrm{Cu}^{2+}$ than $\mathrm{Cu}_{2} \mathrm{~L}^{4+}$ $\left(\mathrm{Cu}_{3} \mathrm{~L}^{6+}+\mathrm{Cu}^{2+}=\mathrm{Cu}_{4} \mathrm{~L}^{8+}, \log \mathrm{K}=16.0\right.$, Table 1$)$, that is, the coordination of the third $\mathrm{Cu}^{2+}$ ion is not very favourable but generates the structural conditions for a favourable continuation of the 
stepwise binding process. Two of the 5 free primary amine groups of $\mathrm{Cu}_{3} \mathrm{~L} 2^{6+}$ become coordinated in $\mathrm{Cu}_{4} \mathrm{~L}_{2}{ }^{8+}$, while no primary amine group appears to be available for protonation in $\mathrm{Cu}_{5} \mathrm{~L}_{2}{ }^{10+}$. The formation of the latter from the tetranuclear complex is accompanied by a small equilibrium constant $\left(\mathrm{Cu}_{4} \mathrm{~L}^{8+}+\mathrm{Cu}^{2+}=\mathrm{Cu}_{5} \mathrm{~L}^{10+}, \log K=9.4\right.$, Table 1$)$ in agreement with the high electrostatic repulsion exerting between the five metal ions and the reduced number of donor atoms remaining available for coordination in $\mathrm{Cu}_{4} \mathrm{~L}^{8+}$. As a matter of fact, the ligand is not able to fulfil the coordination sphere of all five metal ions in $\mathrm{Cu}_{5} \mathrm{~L}^{10+}$ and facile dissociation of coordinated water molecules generates the hydroxo complex $\left[\mathrm{Cu}_{5} \mathrm{~L} 2(\mathrm{OH})_{2}\right]^{8+}$.

In contrast to $\mathrm{Cu}^{2+}$, in the case of $\mathrm{Zn}^{2+}$ complexation, the equilibrium constants for the successive binding of metal ions to form $\mathrm{ZnL2}^{2+}, \mathrm{Zn}_{2} \mathrm{~L}^{4+}, \mathrm{Zn}_{3} \mathrm{~L}^{6+}$ and $\mathrm{Zn}_{4} \mathrm{~L}^{8+}(\log K=17.8,13.2,11.0,10.7$, Table 2) display a more regular trend. The loss of stability from the mono- to the binuclear complex $(\log K=17.8,13.2$, Table 2$)$ is greater than for the corresponding equilibria with $\mathrm{Cu}^{2+}$. Nevertheless, also the stability constants for the formation of $\mathrm{ZnL}^{2+}$ and $\mathrm{Zn}_{2} \mathrm{~L}^{4+}$ are consistent with the stability of hexacoordinated $\mathrm{Zn}^{2+}$ complexes with polyamines [15,16]. According to the criterium based on complex protonation constants, the number of uncoordinated primary amine group should be 9 in $\mathrm{ZnL2}^{2+}$ and 6 in $\mathrm{Zn}_{2} \mathrm{L2}^{4+}$, in agreement with a coordination sphere constituted by three primary and three tertiary nitrogen atoms for both metal ions. Binding of the third $\mathrm{Zn}^{2+}$ ion takes place with further decrease of stability $\left(\mathrm{Zn}_{2} \mathrm{~L}_{2}^{4+}+\mathrm{Zn}^{2+}=\mathrm{Zn}_{3} \mathrm{~L}^{6+}, \log K=11.0\right.$, Table 2$)$. At this stage, another three primary amine groups become involved in metal binding, suggesting a similar hexacoordination for all three metal ions in $\mathrm{Zn}_{3} \mathrm{~L}^{2+}$. An insignificant decrease of binding constant is instead observed at the fourth coordination step $\left(\mathrm{Zn}_{3} \mathrm{~L}^{6+}+\mathrm{Zn}^{2+}=\mathrm{Zn}_{4} \mathrm{~L}^{8+}, \log K=10.7\right.$, Table 2$)$ even though an important reorganization of the trinuclear complex must occur to accommodate the fourth $\mathrm{Zn}^{2+}$ ion. According to protonation data in Table 2, two primary nitrogen atoms should remain uncoordinated in $\mathrm{Zn}_{4} \mathrm{~L}^{8+}$.

Table 2. Stability constants of $\mathrm{Zn}^{2+}$ complexes with L2. $0.10 \mathrm{M} \mathrm{Me}_{4} \mathrm{NCl}, 298.1 \pm 0.1 \mathrm{~K}$. Values in parentheses are standard deviation on the last significant figure.

\begin{tabular}{|c|c|c|c|}
\hline Equilibria & $\log K$ & Equilibria & $\log K$ \\
\hline $\mathrm{Zn}^{2+}+\mathrm{L} 2=\mathrm{ZnL}^{2+}$ & $17.18(5)$ & $\mathrm{Zn}_{2} \mathrm{H}_{6} \mathrm{~L}^{10+}+\mathrm{H}^{+}=\mathrm{Zn}_{2} \mathrm{H}_{7} \mathrm{~L}_{2}{ }^{11+}$ & $8.13(8)$ \\
\hline $\mathrm{ZnL}^{2+}+2 \mathrm{H}^{+}=\mathrm{ZnH}_{2} \mathrm{~L}^{4+}$ & $22.50(8)$ & $\mathrm{Zn}_{2} \mathrm{H}_{7} \mathrm{~L}^{11+}+\mathrm{H}^{+}=\mathrm{Zn}_{2} \mathrm{H}_{8} \mathrm{~L}^{12+}$ & $7.36(7)$ \\
\hline $\mathrm{ZnH}_{2} \mathrm{~L}_{2}^{4+}+\mathrm{H}^{+}=\mathrm{ZnH}_{3} \mathrm{~L}^{5+}$ & $10.04(5)$ & $\mathrm{Zn}_{2} \mathrm{H}_{8} \mathrm{~L}^{12+}+\mathrm{H}^{+}=\mathrm{Zn}_{2} \mathrm{H}_{9} \mathrm{~L}^{13+}$ & $6.47(5)$ \\
\hline $\mathrm{ZnH}_{3} \mathrm{~L}^{5+}+\mathrm{H}^{+}=\mathrm{ZnH}_{4} \mathrm{~L}^{6+}$ & $9.59(6)$ & & \\
\hline $\mathrm{ZnH}_{4} \mathrm{~L}^{6+}+\mathrm{H}^{+}=\mathrm{ZnH}_{5} \mathrm{~L}^{7+}$ & $10.01(7)$ & $3 \mathrm{Zn}^{2+}+\mathrm{L} 2=\mathrm{Zn}_{3} \mathrm{~L}^{6+}$ & $41.36(5)$ \\
\hline $\mathrm{ZnH}_{5} \mathrm{~L}_{2}^{7+}+2 \mathrm{H}^{+}=\mathrm{ZnH}_{7} \mathrm{~L}^{9+}$ & $18.14(7)$ & $\mathrm{Zn}_{2} \mathrm{~L}^{4+}+\mathrm{Zn}^{2+}=\mathrm{Zn}_{3} \mathrm{~L}^{6+}$ & $11.0(1)$ \\
\hline $\mathrm{ZnH}_{7} \mathrm{~L}_{2}{ }^{9+}+\mathrm{H}^{+}=\mathrm{ZnH}_{8} \mathrm{~L}^{10+}$ & $8.25(6)$ & $\mathrm{Zn}_{3} \mathrm{~L}^{6+}+2 \mathrm{H}^{+}=\mathrm{Zn}_{3} \mathrm{H}_{2} \mathrm{~L}^{8+}$ & $22.52(6)$ \\
\hline $\mathrm{ZnH}_{8} \mathrm{~L}_{2}^{10+}+\mathrm{H}^{+}=\mathrm{ZnH}_{9} \mathrm{~L}_{2}^{11+}$ & $8.64(7)$ & $\mathrm{Zn}_{3} \mathrm{H}_{2} \mathrm{~L}^{8+}+\mathrm{H}^{+}=\mathrm{Zn}_{3} \mathrm{H}_{3} \mathrm{~L}^{9+}$ & $9.34(8)$ \\
\hline $\mathrm{ZnH}_{9} \mathrm{~L}^{11+}+\mathrm{H}^{+}=\mathrm{ZnH}_{10} \mathrm{~L}^{12+}$ & $7.97(6)$ & $\mathrm{Zn}_{3} \mathrm{H}_{3} \mathrm{~L}_{2}^{9+}+\mathrm{H}^{+}=\mathrm{Zn}_{3} \mathrm{H}_{4} \mathrm{~L}^{10+}$ & $8.12(8)$ \\
\hline $\mathrm{ZnH}_{10} \mathrm{~L}_{2}^{12+}+\mathrm{H}^{+}=\mathrm{ZnH}_{11} \mathrm{~L}^{13+}$ & $6.92(5)$ & $\mathrm{Zn}_{3} \mathrm{H}_{4} \mathrm{~L}^{10+}+\mathrm{H}^{+}=\mathrm{Zn}_{3} \mathrm{H}_{5} \mathrm{~L}^{11+}$ & $8.00(8)$ \\
\hline $\mathrm{ZnH}_{11} \mathrm{~L}^{13+}+\mathrm{H}^{+}=\mathrm{ZnH}_{12} \mathrm{~L}^{14+}$ & $5.75(4)$ & $\mathrm{Zn}_{3} \mathrm{H}_{5} \mathrm{~L}^{11+}+\mathrm{H}^{+}=\mathrm{Zn}_{3} \mathrm{H}_{6} \mathrm{~L}^{12+}$ & $6.94(6)$ \\
\hline $\mathrm{ZnH}_{12} \mathrm{~L}^{14+}+\mathrm{H}^{+}=\mathrm{ZnH}_{13} \mathrm{~L}^{15+}$ & $5.38(5)$ & $\mathrm{Zn}_{3} \mathrm{H}_{6} \mathrm{~L}^{12+}+\mathrm{H}^{+}=\mathrm{Zn}_{3} \mathrm{H}_{7} \mathrm{~L}^{13+}$ & $6.26(6)$ \\
\hline $2 \mathrm{Zn}^{2+}+\mathrm{L} 2=\mathrm{Zn}_{2} \mathrm{~L}^{4+}$ & $30.35(7)$ & $4 \mathrm{Zn}^{2+}+\mathrm{L} 2=\mathrm{Zn}_{4} \mathrm{~L}^{8+}$ & $52.08(8)$ \\
\hline $\mathrm{ZnL}^{2+}+\mathrm{Zn}^{2+}=\mathrm{Zn}_{2} \mathrm{~L}^{4+}$ & $13.2(1)$ & $\mathrm{Zn}_{3} \mathrm{~L}^{6+}+\mathrm{Zn}^{2+}=\mathrm{Zn}_{4} \mathrm{~L}^{8+}$ & $10.7(1)$ \\
\hline $\mathrm{Zn}_{2} \mathrm{~L}^{4+}+\mathrm{H}^{+}=\mathrm{Zn}_{2} \mathrm{HL}^{5+}$ & $11.27(8)$ & $\mathrm{Zn}_{4} \mathrm{~L}^{8+}+\mathrm{H}^{+}=\mathrm{Zn}_{4} \mathrm{HL}^{9+}$ & $9.48(8)$ \\
\hline $\mathrm{Zn}_{2} \mathrm{HL}_{2}{ }^{+}+\mathrm{H}^{+}=\mathrm{Zn}_{2} \mathrm{H}_{2} \mathrm{~L}^{6+}$ & $11.44(8)$ & $\mathrm{Zn}_{4} \mathrm{HL}_{2}^{9+}+\mathrm{H}^{+}=\mathrm{Zn}_{4} \mathrm{H}_{2} \mathrm{~L}^{10+}$ & $8.90(8)$ \\
\hline $\mathrm{Zn}_{2} \mathrm{H}_{2} \mathrm{~L}^{6+}+\mathrm{H}^{+}=\mathrm{Zn}_{2} \mathrm{H}_{3} \mathrm{~L}^{7+}$ & $9.53(8)$ & $\mathrm{Zn}_{4} \mathrm{H}_{2} \mathrm{~L}^{10+}+\mathrm{H}^{+}=\mathrm{Zn}_{4} \mathrm{H}_{3} \mathrm{~L}^{11+}$ & $8.24(8)$ \\
\hline $\mathrm{Zn}_{2} \mathrm{H}_{3} \mathrm{~L}^{7+}+\mathrm{H}^{+}=\mathrm{Zn}_{2} \mathrm{H}_{4} \mathrm{~L}^{8+}$ & $9.54(8)$ & $\mathrm{Zn}_{4} \mathrm{H}_{3} \mathrm{~L}^{11+}+\mathrm{H}^{+}=\mathrm{Zn}_{4} \mathrm{H}_{4} \mathrm{~L}^{12+}$ & $7.35(9)$ \\
\hline $\mathrm{Zn}_{2} \mathrm{H}_{4} \mathrm{~L}^{8+}+\mathrm{H}^{+}=\mathrm{Zn}_{2} \mathrm{H}_{5} \mathrm{~L}^{9+}$ & $8.80(9)$ & $\mathrm{Zn}_{4} \mathrm{~L}^{8+}+\mathrm{OH}^{-}=\left[\mathrm{Zn}_{4} \mathrm{~L} 2(\mathrm{OH})\right]^{7+}$ & $2.2(1)$ \\
\hline $\mathrm{Zn}_{2} \mathrm{H}_{5} \mathrm{~L}^{9+}+\mathrm{H}^{+}=\mathrm{Zn}_{2} \mathrm{H}_{6} \mathrm{~L}^{10+}$ & $8.60(8)$ & & \\
\hline
\end{tabular}

To get insight into the structural properties of these $\mathrm{Zn}^{2+}$ polynuclear complexes, we performed molecular modelling calculations on $\mathrm{Zn}_{2} \mathrm{~L}^{4+}, \mathrm{Zn}_{3} \mathrm{~L}^{6+}$ and $\mathrm{Zn}_{4} \mathrm{~L}^{8+}$ in a simulated implicit water environment. The lower energy structures obtained for these complexes are shown in Figure 2. According to these structures, in $\mathrm{Zn}_{2} \mathrm{~L}^{4+}$ (Figure 2a) and $\mathrm{Zn}_{3} \mathrm{~L}_{2}{ }^{6+}$ (Figure 2b) each metal ion is coordinated, in a distorted octahedral environment, to six nitrogen atoms pertaining to one arm of the ligand originating from the central tertiary amine group. In agreement with the deductions drawn above from the equilibrium constants, the number of primary nitrogen atoms remaining not 
coordinated is six in $\mathrm{Zn}_{2} \mathrm{~L}^{4+}$ (Figure 2a) and three in $\mathrm{Zn}_{3} \mathrm{~L}^{6+}$ (Figure $2 b$ ). Indeed, the addition of the fourth $\mathrm{Zn}^{2+}$ ion causes a major rearrangement of the trinuclear complex. The ligand displays a great ability to minimize the electrostatic repulsion between metal cations bringing them at long distance from each other (Figure 2c). Only one of the $\mathrm{Zn}^{2+}$ ions retains the octahedral coordination environment seen in the trinuclear complex, while the other three metal cations are: one pentacoordinated by ligand nitrogen atoms, one pentacoordinated by four ligand donors and a water molecule, one tetracoordinated by two ligand donors and two water molecules. The last coordination environment requires some cautionary considerations. In this complex unit, the ligand forms an 8-membered chelate ring including a not coordinated nitrogen atom. A similar arrangement is unlikely to occur in a real solution, since chelate rings of such size are poorly stable. In the simulated implicit water environment of our calculations, however, an overestimation of electrostatic repulsions could have forced the $\mathrm{Zn}^{2+}$ ion to stay as far as possible from the other three cations, instead of involving the third nitrogen atom in the formation of two stable 5-membered chelate rings, which is the situation that we expect to occur in water. Nevertheless, the calculated structure of $\mathrm{Zn}_{4} \mathrm{~L}^{2+}$ (Figure 2c) seems very representative of the overall organization of this complex, as shown by the fact that it implicates the presence of two not coordinated primary nitrogen atoms in agreement with the results deduced above from equilibrium data.
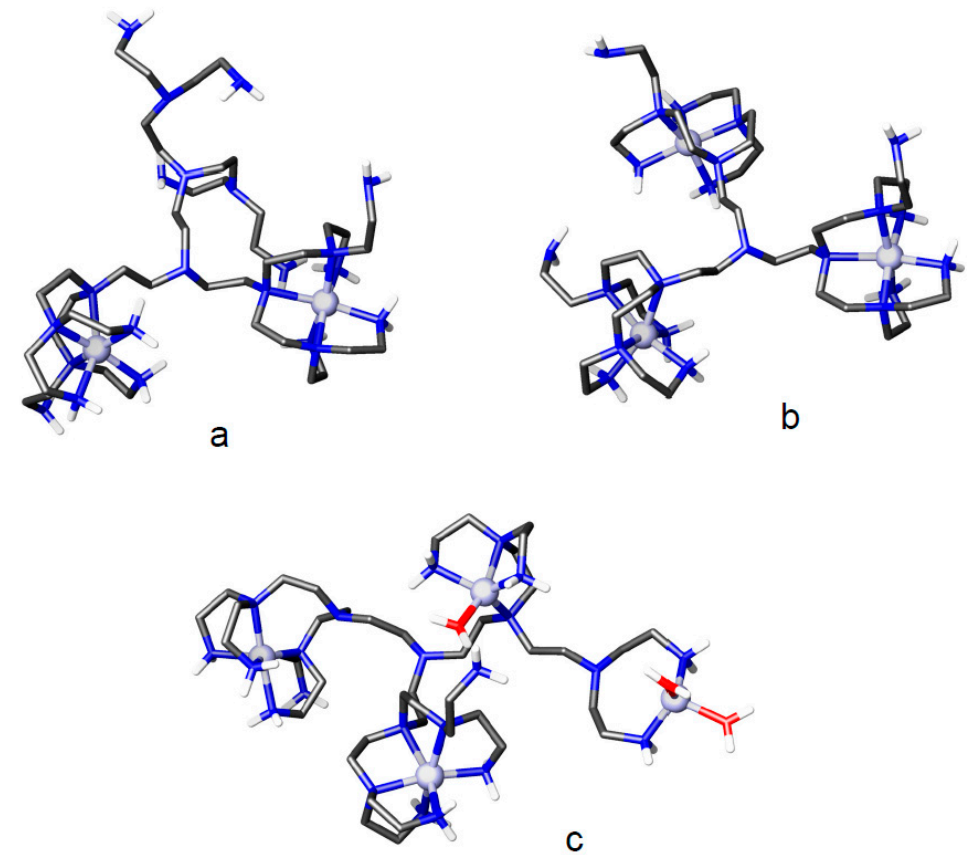

Figure 2. Minimum energy conformations calculated for (a) $\mathrm{Zn}_{2} \mathrm{~L}^{4+}$; (b) $\mathrm{Zn}_{3} \mathrm{~L} 2^{6+}$ and (c) $\mathrm{Zn}_{4} \mathrm{~L}^{8+}$.

\subsection{Formation of Anion and Ion-Pair Complexes}

The detailed analysis of metal complexation equilibria with L2 makes it possible to further investigate such equilibrium systems. For instance, it is possible to analyse the ability of L2 complexes to interact with other species in the environment. We have already seen that protonated forms of L2 can bind $\mathrm{PO}_{4}{ }^{3-}, \mathrm{P}_{2} \mathrm{O}_{7}{ }^{4-}, \mathrm{P}_{3} \mathrm{O}_{10}{ }^{5-}$, and nucleotides (AMP, ADP, ATP) anions in solution [6], and we have already seen that the G-2 dendrimer L1 is able to form both anion and ion-pair complexes [2,3]. We have now studied the equilibria involving $\mathrm{L} 2$ and $\mathrm{SO}_{4}{ }^{2-}$ both in the absence and in the presence of $\mathrm{Cu}^{2+}$ ions by means of $\mathrm{pH}$-metric (potentiometric) titrations $\left(0.1 \mathrm{M} \mathrm{Me}{ }_{4} \mathrm{NCl}, 298.1 \pm 0.1 \mathrm{~K}\right)$. Indeed, the potentiometric data, treated with the computer program HYPERQUAD [12], revealed that many protonated forms of $\mathrm{L} 2$ are able to bind both the $\mathrm{SO}_{4}{ }^{2-}$ anion alone and the $\mathrm{Cu}^{2+} / \mathrm{SO}_{4}{ }^{2-}$ ion-pair. The equilibrium constants for the formation of $\mathrm{SO}_{4}{ }^{2-}$ complexes are reported in Table 3 (see Figure S3 
for a distribution diagram). This table includes the overall constants ( $\beta$ values) for the binding of $\mathrm{SO}_{4}{ }^{2-}$ along with the constants for the equilibria of anion binding by protonated ligand species $\left(\mathrm{H}_{n} \mathrm{~L} 2^{n+}+\mathrm{SO}_{4}{ }^{2-}=\left[\mathrm{H}_{n} \mathrm{~L} 2\left(\mathrm{SO}_{4}\right)\right]^{(n-2)+}\right)$ that could be calculated from the former by using the ligand protonation constants [6]. It is to be noted that the constants for the latter equilibria could not be calculated for complexes $\left[\mathrm{H}_{n} \mathrm{~L} 2\left(\mathrm{SO}_{4}\right)\right]^{(n-2)+}$ with $n<11$ (Table 3), since it was not possible to resolve as single proton binding processes the protonation equilibria involving $\mathrm{H}_{n} \mathrm{~L}^{n+}$ species with $n<11$ [6]. Nonetheless, the stability constants that are available for the binding of $\mathrm{SO}_{4}{ }^{2-}$ to the protonated ligand forms show some peculiarities of this ligand. The stability of anion complexes of polyammonium ligands is generally determined by electrostatic attraction and hydrogen bonding [17-21]. Conversely, the ability of $\mathrm{L} 2$ to bind $\mathrm{SO}_{4}{ }^{2-}$ appears to be unaffected by its positive charge, that is, by its protonation state. Actually, the equilibrium constants for the anion binding vary in a very reduced range and their values are very small, on consideration of the high positive ligand charge and in comparison with $\mathrm{SO}_{4}{ }^{2-}$ complexes of other polyammonium ligands [22]. A similar behaviour was also observed for phosphate and phosphate-like anion complexes with L2, although, in several cases, the stability of these complexes was significantly higher, probably due to the greater hydrogen bond ability of phosphate-like anions [6]. Also the trend of stability is particular: the stability constants decrease from $\mathrm{H}_{11} \mathrm{~L} 2^{11+}(\log \mathrm{K}=3.10)$ to $\mathrm{H}_{13} \mathrm{~L}^{13+}(\log \mathrm{K}=2.46)$, then steadily increase up to the formation of the complex with $\mathrm{H}_{18} \mathrm{~L}^{18+}(\log K=3.32)$.

Table 3. Stability constants of the anion complexes formed by $\mathrm{L} 2$ with $\mathrm{SO}_{4}{ }^{2-} \cdot 0.1 \mathrm{M} \mathrm{Me}_{4} \mathrm{NCl}$, $298.1 \pm 0.1 \mathrm{~K}$. Values in parentheses are standard deviation on the last significant figure.

\begin{tabular}{|c|c|c|c|}
\hline Equilibria & $\log K$ & Equilibria & $\log K$ \\
\hline $\mathrm{L} 2+3 \mathrm{H}^{+}+\mathrm{SO}_{4}^{2-}=\left[\mathrm{H}_{3} \mathrm{~L} 2\left(\mathrm{SO}_{4}\right)\right]^{+}$ & $38.09(5)$ & $\mathrm{H}_{11} \mathrm{~L}^{11+}+\mathrm{SO}_{4}^{2-}=\left[\mathrm{H}_{11} \mathrm{~L} 2\left(\mathrm{SO}_{4}\right)\right]^{9+}$ & $3.10(7)$ \\
\hline $\mathrm{L} 2+5 \mathrm{H}^{+}+\mathrm{SO}_{4}^{2-}=\left[\mathrm{H}_{5} \mathrm{~L} 2\left(\mathrm{SO}_{4}\right)\right]^{3+}$ & $57.88(5)$ & $\mathrm{H}_{12} \mathrm{~L}^{12+}+\mathrm{SO}_{4}{ }^{2-}=\left[\mathrm{H}_{12} \mathrm{~L} 2\left(\mathrm{SO}_{4}\right)\right]^{10+}$ & $2.81(7)$ \\
\hline $\mathrm{L} 2+7 \mathrm{H}^{+}+\mathrm{SO}_{4}^{2-}=\left[\mathrm{H}_{7} \mathrm{~L} 2\left(\mathrm{SO}_{4}\right)\right]^{5+}$ & $76.63(5)$ & $\mathrm{H}_{13} \mathrm{~L}_{2}{ }^{13+}+\mathrm{SO}_{4}{ }^{2-}=\left[\mathrm{H}_{13} \mathrm{~L} 2\left(\mathrm{SO}_{4}\right)\right]^{11+}$ & $2.46(7)$ \\
\hline $\mathrm{L} 2+9 \mathrm{H}^{+}+\mathrm{SO}_{4}^{2-}=\left[\mathrm{H}_{9} \mathrm{~L} 2\left(\mathrm{SO}_{4}\right)\right]^{7+}$ & $94.62(5)$ & $\mathrm{H}_{15} \mathrm{~L}^{15+}+\mathrm{SO}_{4}{ }^{2-}=\left[\mathrm{H}_{15} \mathrm{~L} 2\left(\mathrm{SO}_{4}\right)\right]^{13+}$ & $2.59(7)$ \\
\hline $\mathrm{L} 2+11 \mathrm{H}^{+}+\mathrm{SO}_{4}{ }^{2-}=\left[\mathrm{H}_{11} \mathrm{~L} 2\left(\mathrm{SO}_{4}\right)\right]^{9+}$ & $111.54(5)$ & $\mathrm{H}_{16} \mathrm{~L}^{16+}+\mathrm{SO}_{4}{ }^{2-}=\left[\mathrm{H}_{16} \mathrm{~L} 2\left(\mathrm{SO}_{4}\right)\right]^{14+}$ & $2.76(7)$ \\
\hline $\mathrm{L} 2+12 \mathrm{H}^{+}+\mathrm{SO}_{4}^{2-}=\left[\mathrm{H}_{12} \mathrm{~L} 2\left(\mathrm{SO}_{4}\right)\right]^{10+}$ & $119.58(5)$ & $\mathrm{H}_{17} \mathrm{~L}^{17+}+\mathrm{SO}_{4}{ }^{2-}=\left[\mathrm{H}_{17} \mathrm{~L} 2\left(\mathrm{SO}_{4}\right)\right]^{15+}$ & $2.91(7)$ \\
\hline $\mathrm{L} 2+13 \mathrm{H}^{+}+\mathrm{SO}_{4}^{2-}=\left[\mathrm{H}_{13} \mathrm{~L} 2\left(\mathrm{SO}_{4}\right)\right]^{11+}$ & $127.24(5)$ & $\mathrm{H}_{18} \mathrm{~L}^{18+}+\mathrm{SO}_{4}{ }^{2-}=\left[\mathrm{H}_{18} \mathrm{~L} 2\left(\mathrm{SO}_{4}\right)\right]^{16+}$ & $3.32(7)$ \\
\hline $\mathrm{L} 2+15 \mathrm{H}^{+}+\mathrm{SO}_{4}^{2-}=\left[\mathrm{H}_{15} \mathrm{~L} 2\left(\mathrm{SO}_{4}\right)\right]^{13+}$ & $139.90(5)$ & & \\
\hline $\mathrm{L} 2+16 \mathrm{H}^{+}+\mathrm{SO}_{4}{ }^{2-}=\left[\mathrm{H}_{16} \mathrm{~L} 2\left(\mathrm{SO}_{4}\right)\right]^{14+}$ & $145.53(5)$ & & \\
\hline $\mathrm{L} 2+17 \mathrm{H}^{+}+\mathrm{SO}_{4}{ }^{2-}=\left[\mathrm{H}_{17} \mathrm{~L} 2\left(\mathrm{SO}_{4}\right)\right]^{15+}$ & $149.44(5)$ & & \\
\hline $\mathrm{L} 2+18 \mathrm{H}^{+}+\mathrm{SO}_{4}{ }^{2-}=\left[\mathrm{H}_{18} \mathrm{~L} 2\left(\mathrm{SO}_{4}\right)\right]^{16+}$ & $152.12(5)$ & & \\
\hline
\end{tabular}

To get information about the possibility that such behaviour originates form the structural characteristics of the anion complexes, we performed a molecular modelling calculation on the $\left[\mathrm{H}_{6} \mathrm{~L} 2\left(\mathrm{SO}_{4}\right)\right]^{4+},\left[\mathrm{H}_{12} \mathrm{~L} 2\left(\mathrm{SO}_{4}\right)\right]^{10+}$ and $\left[\mathrm{H}_{15} \mathrm{~L} 2\left(\mathrm{SO}_{4}\right)\right]^{13+}$ species, assuming that the localization of $\mathrm{H}^{+}$ions in the protonated ligand forms is as previously established by ${ }^{1} \mathrm{H}-\mathrm{NMR}$ spectroscopy [6], that is, the first $12 \mathrm{H}^{+}$ions bind the 12 primary $\mathrm{N}(\mathrm{a})$ atoms (Figure 1 ), while in $\mathrm{H}_{15} \mathrm{~L}^{15+}$ the three additional protons involve the three tertiary $\mathrm{N}(\mathrm{c})$ nitrogen atoms. In $\left[\mathrm{H}_{6} \mathrm{~L}_{2}\left(\mathrm{SO}_{4}\right)\right]^{4+}$, protonation was assumed to occur on primary amine groups located as far apart as possible from each other. The minimum energy structures calculated for these complexes, reported in Figure 3, show that the ligand molecule becomes increasingly expanded while becoming increasingly protonated, as a consequence of the increasing electrostatic repulsion exerting between the ammonium groups. In the minimum energy structures of $\left[\mathrm{H}_{6} \mathrm{~L} 2\left(\mathrm{SO}_{4}\right)\right]^{4+}$ (Figure $3 \mathrm{a}$ ) and $\left[\mathrm{H}_{12} \mathrm{~L} 2\left(\mathrm{SO}_{4}\right)\right]^{10+}$ (Figure $3 \mathrm{~b}$ ), the $\mathrm{SO}_{4}{ }^{2-}$ anion forms four salt-bridges (charge reinforced hydrogen bonds) with four ammonium groups of the ligand, while in $\left[\mathrm{H}_{15} \mathrm{~L} 2\left(\mathrm{SO}_{4}\right)\right]^{13+}$ (Figure $3 \mathrm{c}$ ) such interactions drop to three and become longer. Most likely, the two opposite trends developing with increasing ligand protonation, namely (i) the favourable contribution due to the increasing ligand charge; (ii) the unfavourable contribution determined by ligand expansion, are responsible for the particular trend of complex stability showing a minimum for $\mathrm{SO}_{4}{ }^{2-}$ binding by $\mathrm{H}_{13} \mathrm{~L}^{13+}(\log \mathrm{K}=2.46$, Table 3$)$. 

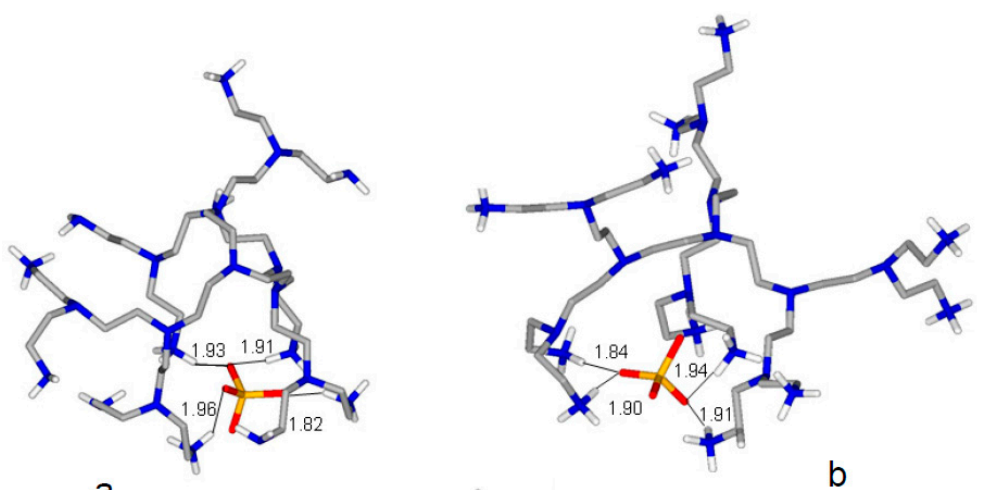

a

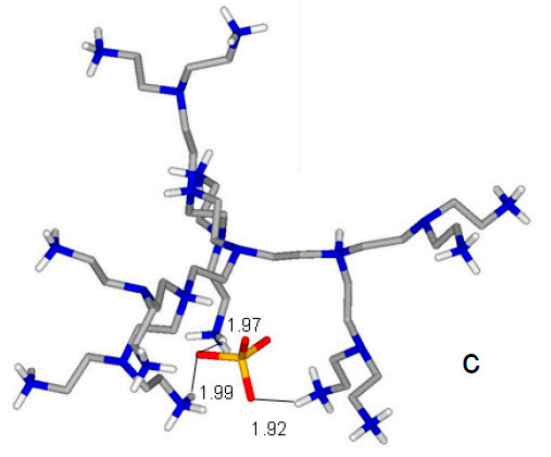

Figure 3. Minimum energy conformations calculated for $(\mathbf{a})\left[\mathrm{H}_{6} \mathrm{~L} 2\left(\mathrm{SO}_{4}\right)\right]^{4+}$; (b) $\left[\mathrm{H}_{12} \mathrm{~L} 2\left(\mathrm{SO}_{4}\right)\right]^{10+}$ and (c) $\left[\mathrm{H}_{15} \mathrm{~L} 2\left(\mathrm{SO}_{4}\right)\right]^{13+}$. Distances are in $\AA$.

As anticipated above, $\mathrm{L} 2$ can bind $\mathrm{SO}_{4}{ }^{2-}$ and $\mathrm{Cu}^{2+}$, simultaneously, forming ion-pair complexes. The equilibrium constants determined for such complexes are presented in Table 4 in the form of equilibrium constants for $\mathrm{SO}_{4}{ }^{2-}$ binding the by $\mathrm{Cu}^{2+}$ complexes of $\mathrm{L} 2$ (see Figure $\mathrm{S} 4$ for a distribution diagram). The analysis of the $\mathrm{L} 2 / \mathrm{Cu}^{2+} / \mathrm{SO}_{4}{ }^{2-}$ system was limited to the formation of ion-pair complexes containing a single metal ion (see the experimental section). Nevertheless, even under the appropriate conditions, the $\left[\mathrm{Cu}_{2} \mathrm{~L} 2\left(\mathrm{SO}_{4}\right)\right]^{2+}$ complex was also found (Table 4), evidencing that more complex ion-pair species including more than one $\mathrm{Cu}^{2+}$ ion can be formed in solution. However, the analysis of such systems, requiring consideration of more than 92 equilibria, did not produced univocal results. This is the reason why we limited our study to ion-pair complexes with a single metal ion.

As can be seen from Table 4, the ability of the protonated $\mathrm{Cu}^{2+}$ complexes to bind $\mathrm{SO}_{4}{ }^{2-}$ increases almost steadily with the positive charge of the metal complex, that is with its protonation state, the unique exception being represented by $\left[\mathrm{CuH}_{10} \mathrm{~L} 2\left(\mathrm{SO}_{4}\right)\right]^{10+}$, whose formation constant appears to be a little bit smaller than that of $\left[\mathrm{CuH}_{9} \mathrm{~L} 2\left(\mathrm{SO}_{4}\right)\right]^{9+}$. An assessment of the ability of the ligand to bind the anion in the absence or in the presence of $\mathrm{Cu}^{2+}$ ions can be performed by direct comparison of the equilibrium constants in Tables 3 and 4, limited to species with $\mathrm{H}_{11} \mathrm{~L}^{11+}$ to $\mathrm{H}_{18} \mathrm{~L}^{18+}$ ligand forms. Such comparison shows that the presence of $\mathrm{Cu}^{2+}$ enhances the ability of these ligand species to bind $\mathrm{SO}_{4}{ }^{2-}$, the increment growing with increasing ligand protonation. For instance, if we consider $\mathrm{SO}_{4}{ }^{2-}$ binding by species with equal positive charge, such as $\mathrm{H}_{18} \mathrm{~L}^{18+}$ and $\mathrm{CuH}_{16} \mathrm{~L}^{18+}$, we observed an increase in stability from $\log K=3.32\left(\mathrm{H}_{18} \mathrm{~L}^{18+}+\mathrm{SO}_{4}{ }^{2-}=\left[\mathrm{H}_{18} \mathrm{~L} 2\left(\mathrm{SO}_{4}\right)\right]^{16+}\right)$ to $\log \mathrm{K}=5.20\left(\mathrm{CuH}_{16} \mathrm{~L} 2^{18+}\right.$ $\left.+\mathrm{SO}_{4}{ }^{2-}=\left[\mathrm{CuH}_{16} \mathrm{~L} 2_{2}\left(\mathrm{SO}_{4}\right)\right]^{16+}\right)$, corresponding to a free energy increment of $11 \mathrm{~kJ} / \mathrm{mol}$. For ligand species in lower protonation state than $\mathrm{H}_{11} \mathrm{~L}^{11+}$, a similar comparison cannot be performed due to the already mentioned impossibility of expressing in the form $\mathrm{H}_{n} \mathrm{~L}^{n+}+\mathrm{SO}_{4}{ }^{2-}=\left[\mathrm{H}_{n} \mathrm{~L}_{2}\left(\mathrm{SO}_{4}\right)\right]^{(n-2)+}$ the formation constants of $\left[\mathrm{H}_{n} \mathrm{~L} 2\left(\mathrm{SO}_{4}\right)\right]^{(n-2)+}$ complexes with $n<11$. To overcome this problem, we can make use of the so called conditional (effective) stability constants that can be calculated for each system, as a function of $\mathrm{pH}$, in the form $K_{\text {eff }}=\Sigma\left[\mathrm{AH}_{i} \mathrm{~L}\right] /\left(\Sigma\left[\mathrm{H}_{j} \mathrm{~L}\right] \times[\mathrm{A}]\right)$, for anion complexes $\left(\mathrm{A}=\mathrm{SO}_{4}{ }^{2-}\right)$, and $K_{\text {eff }}=\Sigma\left[\mathrm{CuAH}_{k} \mathrm{~L}\right] /\left(\Sigma\left[\mathrm{CuH}_{l} \mathrm{~L}\right] \times[\mathrm{A}]\right)$, for ion-pair complexes, where $i, j, k$ and $l$ are 
the number of acidic protons on the ligand in the different species [23]. As can be seen from Figure 4 , which shows the variation with $\mathrm{pH}$ of the effective stability constants calculated for $\mathrm{SO}_{4}{ }^{2-}$ and ion-pair complexes, the presence of $\mathrm{Cu}^{2+}$ promotes the binding of $\mathrm{SO}_{4}{ }^{2-}$ below $\mathrm{pH} 9$, while in the range $9<\mathrm{pH}<10.5$ there is a preference for the metal-free ligand. This behaviour suggests the involvement of the metal ion in the binding of $\mathrm{SO}_{4}{ }^{2-}$ in the ion-pair complexes of higher protonation state. At high $\mathrm{pH}$ values, the ligand is poorly protonated and thus it is able to fulfil the coordination sphere of $\mathrm{Cu}^{2+}$, preventing metal coordination to $\mathrm{SO}_{4}{ }^{2-}$. The ligand wraps around the metal ion leaving less space for $\mathrm{SO}_{4}{ }^{2-}$. Upon protonation of the $\mathrm{Cu}^{2+}$ complex, the ligand becomes less involved in the coordination to the metal and the increasing positive charge of the complex expands its structure, thus making space for the anion to get in contact with $\mathrm{Cu}^{2+}$ and form an increasing number of salt-bridges with ligand ammonium groups. At the break point of these trends ( $\mathrm{pH} 9$ ), the main ion-pair species in solution is $\left[\mathrm{CuH}_{7} \mathrm{~L} 2\left(\mathrm{SO}_{4}\right)\right]^{7+}$ (Figure S4). Below pH 6.5, the separation between the two curves in Figure 4, becomes about 2 logarithm units, which corresponds to the $11 \mathrm{~kJ} / \mathrm{mol}$ free energy increment observed above for the binding of $\mathrm{SO}_{4}{ }^{2-}$ to $\mathrm{CuH}_{16} \mathrm{~L}_{2}{ }^{18+}$ relative to $\mathrm{H}_{18} \mathrm{~L} 2^{18+}$. The formation of contact ion-pair complexes was previously reported for the G-2 dendrimer L1, and is corroborated for L2 by the fact that the binuclear $\mathrm{Cu}_{2} \mathrm{~L}^{4+}$ complex binds $\mathrm{SO}_{4}{ }^{2-}$ (Table 4 ) in the absence of ligand ammonium groups (ligand protonation).

Table 4. Stability constants of the ion-pair complexes formed by $\mathrm{L} 2$ with $\mathrm{Cu}^{2+}$ and $\mathrm{SO}_{4}{ }^{2-} .0 .1 \mathrm{M}$ $\mathrm{Me}_{4} \mathrm{NCl}, 298.1 \pm 0.1 \mathrm{~K}$. Values in parentheses are standard deviation on the last significant figure.

\begin{tabular}{|c|c|}
\hline Equilibria & $\log K$ \\
\hline $\mathrm{CuH}_{3} \mathrm{~L}^{5+}+\mathrm{SO}_{4}^{2-}=\left[\mathrm{CuH}_{3} \mathrm{~L}_{2}\left(\mathrm{SO}_{4}\right)\right]^{3+}$ & $3.10(8)$ \\
\hline $\mathrm{CuH}_{5} \mathrm{~L}^{7+}+\mathrm{SO}_{4}^{2-}=\left[\mathrm{CuH}_{5} \mathrm{~L} 2\left(\mathrm{SO}_{4}\right)\right]^{5+}$ & $3.33(5)$ \\
\hline $\mathrm{CuH}_{7} \mathrm{~L}_{2}{ }^{9+}+\mathrm{SO}_{4}{ }^{2-}=\left[\mathrm{CuH}_{7} \mathrm{~L} 2\left(\mathrm{SO}_{4}\right)\right]^{7+}$ & $3.51(5)$ \\
\hline $\mathrm{CuH}_{9} \mathrm{~L}_{2}{ }^{11+}+\mathrm{SO}_{4}^{2-}=\left[\mathrm{CuH}_{9} \mathrm{~L}_{2}\left(\mathrm{SO}_{4}\right)\right]^{9+}$ & $3.62(5)$ \\
\hline $\mathrm{CuH}_{10} \mathrm{~L}^{12+}+\mathrm{SO}_{4}^{2-}=\left[\mathrm{CuH}_{10} \mathrm{~L} 2\left(\mathrm{SO}_{4}\right)\right]^{10+}$ & $3.44(5)$ \\
\hline $\mathrm{CuH}_{11} \mathrm{~L}_{2}^{13+}+\mathrm{SO}_{4}^{2-}=\left[\mathrm{CuH}_{11} \mathrm{~L} 2\left(\mathrm{SO}_{4}\right)\right]^{11+}$ & $3.69(5)$ \\
\hline $\mathrm{CuH}_{12} \mathrm{~L}^{14+}+\mathrm{SO}_{4}^{2-}=\left[\mathrm{CuH}_{12} \mathrm{~L} 2\left(\mathrm{SO}_{4}\right)\right]^{12+}$ & $3.96(5)$ \\
\hline $\mathrm{CuH}_{13} \mathrm{~L}_{2}^{15+}+\mathrm{SO}_{4}^{2-}=\left[\mathrm{CuH}_{13} \mathrm{~L} 2\left(\mathrm{SO}_{4}\right)\right]^{13+}$ & $4.31(5)$ \\
\hline $\mathrm{CuH}_{14} \mathrm{~L}_{2}^{16+}+\mathrm{SO}_{4}^{2-}=\left[\mathrm{CuH}_{14} \mathrm{~L} 2\left(\mathrm{SO}_{4}\right)\right]^{14+}$ & $4.64(5)$ \\
\hline $\mathrm{CuH}_{16} \mathrm{~L}^{18+}+\mathrm{SO}_{4}^{2-}=\left[\mathrm{CuH}_{16} \mathrm{~L} 2\left(\mathrm{SO}_{4}\right)\right]^{16+}$ & $5.20(5)$ \\
\hline$\left[\mathrm{CuH}_{16} \mathrm{~L} 2\left(\mathrm{SO}_{4}\right)\right]^{16+}+\mathrm{H}+=\left[\mathrm{CuH}_{17} \mathrm{~L} 2\left(\mathrm{SO}_{4}\right)\right]^{17+}$ & $2.78(5)$ \\
\hline $\mathrm{Cu}_{2} \mathrm{~L}^{4+}+\mathrm{SO}_{4}^{2-}=\left[\mathrm{Cu}_{2} \mathrm{~L} 2\left(\mathrm{SO}_{4}\right)\right]^{2+}$ & $4.01(5)$ \\
\hline
\end{tabular}

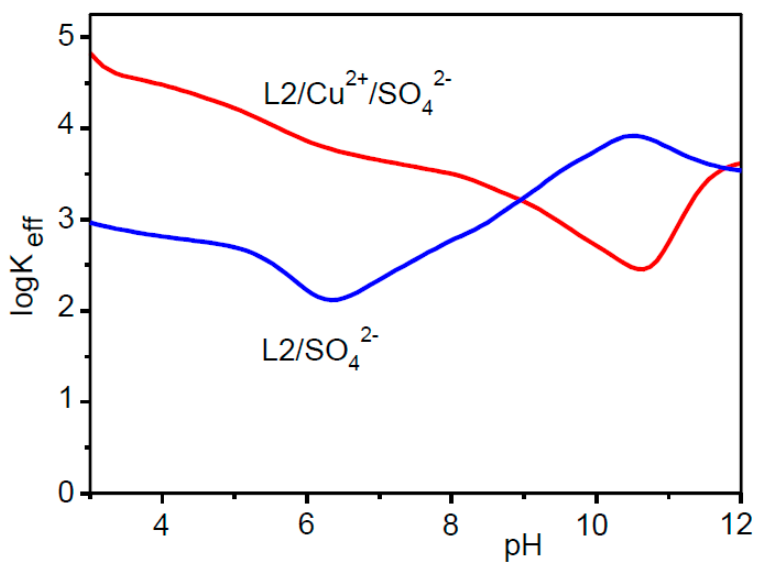

Figure 4. Logarithms of the conditional stability constants of anion $\left(\mathrm{SO}_{4}{ }^{2-}\right)$ and ion-pair $\left(\mathrm{Cu}^{2+} / \mathrm{SO}_{4}{ }^{2-}\right)$ complexes with L2. 


\section{Materials and Methods}

\subsection{General Information}

All starting materials were high purity compounds purchased from commercial sources and used as supplied. Ligand L2 was synthetized according to a previously described procedure [24].

\subsection{Potentiometric Measurements}

Potentiometric ( $\mathrm{pH}$-metric) titrations, employed to determine equilibrium constants, were performed in $0.1 \mathrm{M} \mathrm{Me}_{4} \mathrm{NCl}$ aqueous solution at $298.1 \pm 0.1 \mathrm{~K}$ by using an automated system and a procedure already described [25]. The combined Metrohm 6.0262.100 electrode (Metrohm AG, Herisau, Switzerland) was calibrated as a hydrogen-ion concentration probe by titration of previously standardized amounts of $\mathrm{HCl}$ with $\mathrm{CO}_{2}$-free $\mathrm{NMe}_{4} \mathrm{OH}$ solutions and determining the equivalent point by Gran's method [26], which gives the standard potential, $E^{\circ}$, and the ionic product of water $\left(\mathrm{p} K_{\mathrm{w}}=13.83(1)\right.$ in $0.1 \mathrm{M} \mathrm{Me}_{4} \mathrm{NCl}$ at $\left.298.1 \pm 0.1 \mathrm{~K}\right)$. The computer program HYPERQUAD [12] was used to calculate complex stability constants. All experiments were performed in the $\mathrm{pH}$ range 2.5-11.0 with $1 \times 10^{-3} \mathrm{M}$ ligand concentration. Six titrations in the case of $\mathrm{Cu}^{2+}$ complexation, and five in the case of $\mathrm{Zn}^{2+}$, were performed with metal concentration varying in the ranges $0.5[\mathrm{~L}] \leq\left[\mathrm{Cu}^{2+}\right] \leq$ $4.5[\mathrm{~L}]$ and $0.5[\mathrm{~L}] \leq\left[\mathrm{Zn}^{2+}\right] \leq 3.5[\mathrm{~L}]$. Metal to ligand molar ratios greater than 5 for $\mathrm{Cu}^{2+}$ and 4 for $\mathrm{Zn}^{2+}$ were also tested: precipitation of metal hydroxide was observed in alkaline solution, while the analysis of the acidic branches of the titrations confirmed the maximum nuclearity of 5 for $\mathrm{Cu}^{2+}$ and 4 for $\mathrm{Zn}^{2+}$. Three titrations were performed for anion binding with $\mathrm{SO}_{4}{ }^{2-}$ concentration in the range $2[\mathrm{~L}] \leq\left[\mathrm{SO}_{4}{ }^{2-}\right] \leq 5[\mathrm{~L}]$. Three titrations were performed for ion-pair binding with $\left[\mathrm{Cu}^{2+}\right]=0.8[\mathrm{~L}]$ and $\mathrm{SO}_{4}{ }^{2-}$ concentration $2[\mathrm{~L}] \leq\left[\mathrm{SO}_{4}{ }^{2-}\right] \leq 5[\mathrm{~L}]$. The different titration curves, obtained for metal, anion and ion-pair complexation experiments, respectively, were treated as separated curves without significant variations in the values of the common stability constants. Finally, the sets of data were merged together and treated simultaneously to give the final stability constants. Different equilibrium models for the complex systems were generated by eliminating and introducing different species. Only those models for which the HYPERQUAD program furnished a variance of residuals $\sigma^{2} \leq 9$ were accepted. This condition was unambiguously met by a single model. Ligand protonation constants were taken from the literature [6].

\subsection{Molecular Modelling}

Molecular modelling investigations on $\left[\mathrm{H}_{6} \mathrm{~L} 2\left(\mathrm{SO}_{4}\right)\right]^{4+},\left[\mathrm{H}_{12} \mathrm{~L} 2\left(\mathrm{SO}_{4}\right)\right]^{10+}$ and $\left[\mathrm{H}_{15} \mathrm{~L}_{2}\left(\mathrm{SO}_{4}\right)\right]^{13+}$ complexes were performed by means of the empirical force field method AMBER3 as implemented in the Hyperchem 7.51 package [27], using an implicit simulation of aqueous environment $(\varepsilon=4 \mathrm{r})$ and atomic charged evaluated at the semiempirical level of theory (PM3) [28,29]. Potential energy surface of all the systems were explored by means of simulated annealing $(\mathrm{T}=600 \mathrm{~K}$, equilibration time $=10 \mathrm{ps}$, run time $=10 \mathrm{ps}$ and cooling time $=10 \mathrm{ps}$, time step $=1.0 \mathrm{fs}$ ). For each studied system, 80 conformations were sampled.

As for the $\mathrm{Zn}(\mathrm{II})$ complexes, the trinuclear $\mathrm{Zn}_{3} \mathrm{~L} 2^{6+}$ species was firstly analysed. Starting coordinates were built from the crystal structure of the $\mathrm{Ni}^{2+}$ complex of L1 [1], containing $\mathrm{Ni}^{2+}$ ions hexacoordinated in distorted octahedral environments to six out of the seven nitrogen atoms constituting a portion of L1 that is identical to the three branches of L2 growing from the central N(c) atom (Figure 1). The nitrogen atom remaining uncoordinated is a primary one. This structural motif was chosen taking into account that, according to the equilibrium data discussed before, all three metal ions of $\mathrm{Zn}_{3} \mathrm{~L}^{6+}$ should be hexacoordinated and three primary amine groups of the complex should not be involved in metal coordination. This crystallographic structural unit was firstly modified by replacing $\mathrm{Ni}^{2+}$ with $\mathrm{Zn}^{2+}$ and completing each coordination environment with water molecules.

The starting coordinates for the binuclear $\mathrm{Zn}_{2} \mathrm{~L}^{4+}$ complex were obtained by deleting one zinc ion in the QM minimized structure of $\mathrm{Zn}_{3} \mathrm{~L} 2^{6+}$. The tetranuclear $\mathrm{Zn}_{4} \mathrm{~L}^{8+}$ complex was instead obtained 
from the QM minimized binuclear complex by adding to its metal-free branch two QM minimized pentacoordinated $\mathrm{Zn}^{2+}$ complexes, one in square pyramidal and one in bipyramidal geometry, taken from the crystallographic structure of the trinuclear $\mathrm{Cu}^{2+}$ complex of L1 [1] and successively modified by replacing $\mathrm{Cu}^{2+}$ with $\mathrm{Zn}^{2+}$.

The starting coordinates for each polynuclear complexes were firstly optimized by using the OPLS2005 forcefield implemented in the Impact software [30], with completely frozen metals and coordination environments. Then, each MM minimized structure was fully optimized at the DFT/M06 level of theory [31,32] by using the $6-31 \mathrm{~g}(\mathrm{tm})$ basis set [33-37] and the implicit simulation for the aqueous environment [38]. The nature of stationary points as true minima was checked by frequency calculations.

\section{Conclusions}

The ability of L2 to form stable highly nucleated complexes over a large $\mathrm{pH}$ range, as a consequence of its dendrimeric nature and of the many amine groups in its structure, make this compound a promising candidate for the preparation of solid supported materials to be used in the recovery of metal ions from aqueous media. This could find applications in both decontamination of waste waters and in the extraction of precious metals. Indeed, it was recently reported that activated carbon functionalized with randomly structured poly(ethylene imine) dendrimers are efficient scavenger of $\mathrm{Pd}^{2+}$ cations [39]. Moreover, L2 is also a promising candidate for catalytic purposes. The use of molecules with well-defined molecular structures, such as L2, has the advantage that with such molecules it is possible to perform a confident speciation of the complexes they form in solution, thus getting a fundamental instrument for the tailoring of appropriate receptors for substrates binding and activation. This is of special interest when the supported complex is used for catalytic purposes. Considering the ability of L2 to form complexes with many metal centres that may promote the binding of further species from the medium, we are particularly interested in developing carbon materials (activated carbons, carbon nanotubes, graphene) functionalized with L2 and testing them for catalytic applications in reaction for the formation of carbon-carbon bonds, such as the Sonogashira cross coupling.

Supplementary Materials: The following are available online: Figure S1: Distribution diagrams of the $\mathrm{Cu}^{2+}$ complexes of L2, Figure S2: Distribution diagrams of the $\mathrm{Zn}^{2+}$ complexes of L2, Figure S3: Distribution diagrams of the anion complexes formed by $\mathrm{L} 2$ with $\mathrm{SO}_{4}{ }^{2-}$, Figure S4: Distribution diagrams of the ion-pair complexes formed by $\mathrm{L} 2$ with $\mathrm{Cu}^{2+}$ and $\mathrm{SO}_{4}{ }^{2-}$ complexes of $\mathrm{L} 2$.

Acknowledgments: Financial support from the Italian MIUR (project 2015MP34H3) is gratefully acknowledged.

Author Contributions: All authors conceived and designed the experiments; M.S. performed the synthesis and part of the potentiometric measurements; C.B. and P.G. performed the modelling calculations; C.G. performed part of the potentiometric measurements and took care of the graphical presentation of results; A.B. wrote the paper.

Conflicts of Interest: The authors declare no conflict of interest.

\section{References}

1. Bazzicalupi, C.; Bianchi, A.; Giorgi, C.; Gratteri, P.; Mariani, P.; Valtancoli, B. Metal ion binding by a G-2 Poly(ethylene imine) dendrimer. Ion-directed self-assembling of hierearchical mono- and two-dimensional nanostructured materials. Inorg. Chem. 2013, 52, 2125-2137. [CrossRef] [PubMed]

2. Bazzicalupi, C.; Bianchi, A.; Giorgi, C.; Gratteri, P.; Mariani, P.; Valtancoli, B. Anion and ion-pair binding by a G-2 Poly(ethylene imine) dendrimer. Dalton Trans. 2013, 42, 12130-12138. [CrossRef] [PubMed]

3. Bazzicalupi, C.; Bianchi, A.; Giorgi, C.; Valtancoli, B. Zn(II) enhances nucleotide binding and dephosphorilation in the presence of a Poly(ethylene imine) dendrimer. Inorg. Chim. Acta 2014, 417, 163-170. [CrossRef]

4. Salvador Serrano, E.; Savastano, M.; Bianchi, A. Inorganic Mercury Sequestration by a Poly(ethylene imine) Dendrimer in Aqueous Solution. Molecules 2015, 20, 3783-3790. [CrossRef] [PubMed]

5. Bazzicalupi, C.; Bencini, A.; Bianchi, A.; Danesi, A.; Giorgi, C.; Valtancoli, B. Anion Binding by Protonated Forms of the Tripodal Ligand Tren. Inorg. Chem. 2009, 48, 2391-2398. [CrossRef] [PubMed] 
6. Bazzicalupi, C.; Bianchi, A.; Giorgi, C.; Savastano, M.; Morales-Lara, F. ATP dephosphorylation can be either enhanced or inhibited by $\mathrm{pH}$-controlled interaction with a dendrimer molecule. Chem. Commun. 2015, 51, 3907-3910. [CrossRef] [PubMed]

7. Astruc, D.; Wang, D.; Deraedt, C.; Liang, L.; Ciganda, R.; Ruiz, J. Catalysis Inside Dendrimers. Synthesis 2015, 47, 2017-2031. [CrossRef]

8. Wang, D; Astruc, D. Dendritic catalysis-Basic concepts and recent trends. Coord. Chem. Rev. 2013, 257, 2317-2334. [CrossRef]

9. Myers, V.S.; Weir, M.G.; Carino, E.V.; Yancey, D.F.; Pande, S.; Crooks, R.M. Dendrimer-encapsulated nanoparticles: New synthetic and characterization methods and catalytic applications. Chem. Sci. 2011, 2, 1632-1646. [CrossRef]

10. Hwang, S.-H.; Shreiner, C.D.; Moorefield, C.N.; Newkome, G.W. Recent progress and applications for metallodendrimers. New J. Chem. 2007, 31, 1192-1217. [CrossRef]

11. Jarvis, N.V.; Wagener, J.M. Mechanistic studies of metal ion binding to water-soluble polymers using potentiometry. Talanta 1995, 42, 219-226. [CrossRef]

12. Gans, P.; Sabatini, A.; Vacca, A. Investigation of equilibria in solution. Determination of equilibrium constants with the HYPERQUAD suite of programs. Talanta 1996, 43, 1739-1753. [CrossRef]

13. Aragó, J.; Bencini, A.; Bianchi, A.; Garcia-España, E.; Micheloni, M.; Paoletti, P.; Ramirez, J.A.; Paoli, P. Interaction of "long" open-chain polyazaalkanes with hydrogen and copper(II) ions. Inorg. Chem. 1991, 30, 1843-1849. [CrossRef]

14. Bencini, A.; Bianchi, A.; Micheloni, M.; Paoletti, P.; Garcia-España, E.; Niño, M.A. Co-ordination tendency of $[3 k]$ aneN $_{k}$ polyazacycloalkanes. Thermodynamic study of solution equilibria. J. Chem. Soc. Dalton Trans. 1991, 1171-1174. [CrossRef]

15. Aragó, J.; Bencini, A.; Bianchi, A.; Garcia-España, E.; Micheloni, M.; Paoletti, P.; Ramirez, J.A.; Rodriguez, A. Interaction of long polyazaalkanes with zinc(II) and cadmium(II) ions. A thermodynamic and ${ }^{13} \mathrm{C}$ nuclear magnetic resonance study. J. Chem. Soc. Dalton Trans. 1991, 3077-3083. [CrossRef]

16. Bencini, A.; Bianchi, A.; Dapporto, P.; Garcia-España, E.; Micheloni, M.; Paoletti, P. Polynuclear zinc(II) complexes with large polyazacycloalkanes. 2. Equilibrium study and crystal structure of the binuclear complex $\left[\mathrm{Zn}_{2} \mathrm{LCl}_{2}\right](\mathrm{Cl}) \mathrm{ClO}_{4} \cdot \mathrm{H}_{2} \mathrm{O}(\mathrm{L}=1,4,7,10,13,16,19,22$-octaazacyclotetracosane). Inorg. Chem. 1989, 28, 1188-1191. [CrossRef]

17. Anion Coordination Chemistry; Bowman-James, K., Bianchi, A., García-España, E., Eds.; Wiley-VCH: New York, NY, USA, 2012.

18. Mateus, P.; Bernier, N.; Delgado, R. Recognition of anions by polyammonium macrocyclic and cryptand receptors: Influence of the dimensionality on the binding behavior. Coord. Chem. Rev. 2010, 254, 1726-1747. [CrossRef]

19. Bowman-James, K. Alfred Werner Revisited: The Coordination Chemistry of Anions. Acc. Chem. Res. 2005, 38, 671-678. [CrossRef] [PubMed]

20. Garcia-España, E.; Díaz, P.; Llinares, J.M.; Bianchi, A. Anion coordination chemistry in aqueous solution of polyammonium receptors. Coord. Chem. Rev. 2006, 250, 2952-2986. [CrossRef]

21. Bianchi, A.; Micheloni, M.; Paoletti, P. Supramolecular interaction between adenosine $5^{\prime}$-triphosphate (ATP) and polycharged tetraazamacrocycles. Thermodynamic and ${ }^{31}$ P NMR studies. Inorg. Chim. Acta 1988, 151, 269-272. [CrossRef]

22. Arranz, P.; Bencini, A.; Bianchi, A.; Díaz, P.; Garcia-España, E.; Giorgi, C.; Luis, S.V.; Querol, M.; Valtancoli, B. Thermodynamics of sulfate anion binding by macrocyclic polyammonium receptors. J. Chem. Soc. Perkin Trans. 2001, 1765-1770. [CrossRef]

23. Bazzicalupi, C.; Bianchi, A.; Giorgi, C.; Clares, M.P.; Garcia-España, E. Addressing selectivity criteria in binding equilibria. Coord. Chem. Rev. 2011, 256, 13-27. [CrossRef]

24. Lee, S.H.; Kim, D.-J.; Chang, C.-C.; Hah, S.S.; Suh, J. An efficient synthesis of ethylenimine dendrimer. Bull. Korean Chem. Soc. 1998, 19, 1270-1273.

25. Bazzicalupi, C.; Bianchi, A.; Biver, T; Giorgi, C.; Santarelli, S.; Savastano, M. Formation of double-strand dimetallic helicates with a terpyridine-based macrocycle. Inorg. Chem. 2014, 53, 12215-12224. [CrossRef] [PubMed]

26. Gran, G. Determination of the equivalence point in potentiometric titration, Part II. Analyst 1952, 77, 661-671. [CrossRef] 
27. Hyperchem, Release 7.51 for Windows MM System; Hypercube, Inc.: Gainesville, FL, USA, 2002.

28. Stewart, J.J.P. Optimization of parameters for semiempirical methods I. Method. J. Comput. Chem. 1989, 10, 209-220. [CrossRef]

29. Stewart, J.J.P. Optimization of parameters for semiempirical methods II. Applications. J. Comput. Chem. 1989, 10, 221-264. [CrossRef]

30. Banks, J.L.; Beard, H.S.; Cao, Y.; Cho, A.E.; Damm, W.; Farid, R.; Felts, A.K.; Halgren, T.A.; Mainz, D.T.; Maple, J.R.; et al. Integrated Modeling Program, Applied Chemical Theory (IMPACT). J. Comput. Chem. 2005, 26, 1752-1780. [CrossRef] [PubMed]

31. Kohn, W.; Sham, L.J. Self-Consistent Equations Including Exchange and Correlation Effects. Phys. Rev. 1965, 140, A1133-A1138. [CrossRef]

32. Zhao, Y.; Truhlar, D.G. The M06 suite of density functionals for main group thermochemistry, thermochemical kinetics, noncovalent interactions, excited states, and transition elements: Two new functionals and systematic testing of four M06-class functionals and 12 other functionals. Theor. Chem. Acc. 2008, 120, 215-241.

33. Ditchfield, R.; Hehre, W.J.; Pople, J.A. Self-Consistent Molecular-Orbital Methods. IX. An Extended Gaussian-Type Basis for Molecular-Orbital Studies of Organic Molecules. J. Chem. Phys. 1971, 54, 724-728. [CrossRef]

34. Hehre, W.J.; Pople, J.A. Self-Consistent Molecular Orbital Methods. XIII. An Extended Gaussian Type Basis for Boron. J. Chem. Phys. 1972, 56, 4233-4234. [CrossRef]

35. Binkley, J.S.; Pople, J.A. Self-Consistent Molecular Orbital Methods. XIX. Split Valence Gaussian-type Basis Sets for Beryllium. J. Chem. Phys. 1977, 66, 879-880. [CrossRef]

36. Hariharan, P.C.; Pople, J.A. The Influence of Polarization Functions on Molecular Orbital Hydrogenation Energies. Theor. Chim. Acta 1973, 28, 213-222. [CrossRef]

37. Mitin, A.V.; Baker, J.; Pulay, P. An improved 6-31G* basis set for first-row transition metals. J. Chem. Phys. 2003, 119, 7775-7782. [CrossRef]

38. Cortis, M.C.; Friesner, R.A. Poisson-Boltzmann Calculations of Nonspecific Salt Effects on Protein-Protein Binding Free Energies. J. Comput. Chem. 1997, 18, 1591-1608. [CrossRef]

39. Peñas-Sanjuán, A.; López-Garzón, R.; López-Garzón, J.; Pérez-Mendoza, M.; Melguizo, M. Preparation of a poly-alkylamine surface-functionalized carbon with excellent performance as a $\mathrm{Pd}(\mathrm{II})$ scavenger. Carbon 2012, 50, 2350-2352. [CrossRef]

Sample Availability: Samples of the compound L2 is available from the authors.

(C) 2017 by the authors. Licensee MDPI, Basel, Switzerland. This article is an open access article distributed under the terms and conditions of the Creative Commons Attribution (CC BY) license (http:/ / creativecommons.org/licenses/by/4.0/). 